\title{
Liposome Encapsulation of Lipophilic $N$-Alkyl-propanediamine Platinum Complexes: Impact on their Cytotoxic Activity and Influence of the Carbon Chain Length
}

\author{
Heveline Silva, ${ }^{a}$ Ana Paula S. Fontes, ${ }^{a}$ Miriam Teresa P. Lopes ${ }^{b}$ and Frédéric Frézard ${ }^{*, c}$ \\ ${ }^{a}$ Departamento de Química, Universidade Federal de Juiz de Fora, \\ 36036-900 Juiz de Fora-MG, Brazil \\ ${ }^{b}$ Departamento de Farmacologia, Universidade Federal de Minas Gerais, \\ 31270-901 Belo Horizonte-MG, Brazil \\ ${ }^{c}$ Departamento de Fisiologia e Biofísica, Universidade Federal de Minas Gerais, \\ 31270-901 Belo Horizonte-MG, Brazil
}

\begin{abstract}
Complexos de platina(II) derivados de $N$-alquil-propanodiamina com cadeia carbônica variável $(\mathrm{C} 8, \mathrm{C} 10, \mathrm{C} 12$ ou $\mathrm{C} 14)$ foram incorporados em lipossomas e a atividade citotóxica dessas formulações foi avaliada em linhagens tumorais ( $\mathrm{A}_{549}$, MDA-MB-231, B16-F1 and B16-F10) e nãotumorais (BHK-21 and CHO). Suspensões de lipossomas estáveis e monodispersas incorporando os complexos de platina foram obtidas com uma composição lipídica de diestearoil-sn-glicero3-fosfocolina, colesterol, e 1,2-diestearoil-sn-glicero-3-fosfoetanolamina- $N$-(metoxi(polietilenoglicol)-2000) na razão molar 5:3:0,3. A eficiência da incorporação dos complexos de platina em lipossomas aumentou com o tamanho da cadeia carbônica e foi maior que $80 \%$ com os derivados $\mathrm{C} 12$ e C14. O efeito da encapsulação em lipossomas na atividade citotóxica dos complexos mostrouse dependente do tamanho da cadeia carbônica. Os dados indicam que a biodisponibilidade da platina a partir das formulações de lipossomas foi maior para o complexo apresentando uma cadeia carbônica (C12) e uma partição entre a membrana e a fase aquosa intermediárias.
\end{abstract}

Antitumor platinum(II) complexes derived from $\mathrm{N}$-alkyl-propanediamine differing in the length of their carbon chain $(\mathrm{C} 8, \mathrm{C} 10, \mathrm{C} 12$ and $\mathrm{C} 14)$ were incorporated in liposomes and the cytotoxic activity of these formulations was evaluated against tumor $\left(\mathrm{A}_{549}, \mathrm{MDA}-\mathrm{MB}-231, \mathrm{~B} 16-\mathrm{F} 1\right.$ and B16-F10) and non-tumor (BHK-21 and CHO) cell lines. Stable and monodisperse liposome suspensions incorporating the platinum complexes were obtained from the lipid composition consisting of distearoyl-sn-glycero-3-phosphocholine, cholesterol and 1,2-distearoyl-sn-glycero3 -phophoethanolamine- $N$-(methoxy(polyethylene glycol)-2000) at 5:3:0.3 molar ratio. The entrapment efficiency (EE\%) of the platinum complexes in liposomes increased with the carbon chain length. EE\% was higher than $80 \%$ in C12- and C14-derivatives. The effect of liposome encapsulation on the cytotoxic activity of the complexes was found to depend on the carbon chain length. These data indicate that the highest drug bioavailability from liposome formulations was achieved with the complex showing intermediate carbon chain length and partition between the liposome membrane and aqueous phase.

Keywords: liposomes, platinum complexes, cytotoxic activity

\section{Introduction}

Cancer is one of the leading causes of death in the world, with chemotherapy being a valuable tool for the treatment of the disease. The development of novel compounds which are more effective and less toxic and which could become

*e-mail: frezard@icb.ufmg.br eventual anti-tumor drugs constitutes a research area of great relevance.

Platinum complexes are well established anti-tumor agents in clinical use, with cisplatin being the most widely used compound of this class. ${ }^{1-3}$ However, their use has been compromised by its propensity to cause several toxicities including nephrotoxicity, neurotoxicity and ototoxicity $^{4-6}$ and the emergence of platinum resistance, 
specially caused by the reduction of intracellular platinum accumulation. ${ }^{78}$ Lipophilic derivatives of platinum(II) have been investigated for their ability to enhance the cellular uptake of platinum in both cisplatin-sensitive and resistant cell lines. ${ }^{9,10}$

Nanocarriers have been a fundamental tool in cancer research. Currently, natural and synthetic polymers and lipids are typically used as components of drug delivery nanovectors. The family of nanocarriers includes polymer conjugates, polymeric nanoparticles, lipid-based carriers such as liposomes and micelles, dendrimers, carbon nanotubes, and gold nanoparticles, including nanoshells and nanocages. Rationally designed nanocarriers can offer several therapeutic advantages over free drugs. Liposomes have attractive biological properties, including general biocompatibility, biodegradability, isolation of drugs from the surrounding environment, and the ability to entrap both hydrophilic and hydrophobic drugs and today are approved by regulatory agencies to carry a range of chemotherapeutics. ${ }^{11}$

The encapsulation of lipophilic derivatives of cisplatin in liposomes has been explored to allow for the safe parenteral administration of these complexes. ${ }^{12-14}$ In addition to their solubilization properties, liposomes have been extensively studied for the passive and active targeting of drug to tumors..$^{15}$ For instance, the use of polyethylene glycol as PEG-coated liposomes was found to prolong the circulation time of liposomes in blood, to passively enhance their tumor localization, and improve the therapeutic efficacy of platinum complexes, exploring the EPR (enhanced permeability and retention) effect. ${ }^{16}$ As another potential benefit, liposome encapsulation may also circumvent drug resistance of tumor cells, as reported previously for cisplatin. ${ }^{17,18}$

Although several lipophilic drugs have been prepared and evaluated under the encapsulated form in liposomes, the physicochemical factors that determine the bioavailability of a lipophilic drug from a liposome carrier are still poorly understood. In particular, the influence of the carbon chain length/partition coefficient has not been systematically investigated.

This work describes the effective and stable encapsulation in PEGylated liposomes of four $N$-alkylpropanediamine platinum complexes differing in the length of their carbon chain. The cytotoxic activity of these liposome formulations was assessed against tumor and normal cell lines and compared to that of the free platinum compounds, cisplatin and carboplatin. The influence of hydrophilic/hydrophobic balance of the platinum complex is discussed.

\section{Experimental}

\section{Materials}

Distearoyl-sn-glycero-3-phosphocholine (DSPC), 1,2-distearoyl-sn-glycero-3-phophoethanolamine- $N$ (methoxy(polyethylene glycol)-2000 (DSPE-PEG) and soybean phosphatidylcholine (SPC) were obtained from Lipoid AG. 1-(4,5-Dimethylthiazol-2-yl)-3,5diphenylformazan (MTT), cholesterol $(\mathrm{CH})$ and dicetylphosphate (DCP) were obtained from Sigma Chemical Co (St. Louis, MO, USA). All other chemicals were reagent-grade and were used without further purification.

\section{Synthesis of platinum complexes}

Complexes 1, 2, 3 and 4 (Figure 1) were synthesized as previously described.$^{19}$ Briefly, the platinum(II) complexes were obtained by reaction of the corresponding ligands with potassium tetrachloroplatinate(II) in a water/methanol mixture at room temperature for $24 \mathrm{~h}$, and were isolated by simple filtration. The results of the characterization of these complexes by elemental analyses, infrared spectroscopy and ${ }^{1} \mathrm{H},{ }^{13} \mathrm{C}$ and ${ }^{195} \mathrm{Pt}$ NMR spectroscopy have been presented in our previous work. ${ }^{19}$ The purity of the compounds was confirmed by elemental analyses.

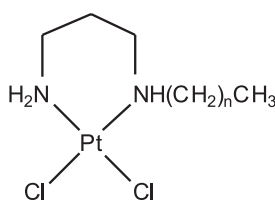

$1 \mathrm{n}=7$, Dichloro-( $N$-octyl)-propanediamine-platinum(II)

$2 \mathrm{n}=9$, Dichloro-( $N$-decyl)-propanediamine-platinum(II)

$3 \mathrm{n}=1$, , Dichloro-( $N$-dodecyl)-propanediamine-platinum(II)

$4 \mathrm{n}=13$, Dichloro-( $N$-tetradecyl)-propanediamine-platinum(II)

Figure 1. Lipophilic platinum complexes.

Preparation of the liposome formulation of platinum complex

Multilamellar vesicles (MLV) containing the platinum complexes were prepared according to the thin film hydration method, followed by the extrusion process for liposome size calibration..$^{20,21}$

Briefly, lipids and each platinum complex were mixed and dissolved in chloroform. The following lipid compositions were evaluated: $\mathrm{CH} /$ complex at 3:7 molar ratio, $\mathrm{DCP} / \mathrm{CH} /$ complex at 2:3:5 molar ratio, $\mathrm{SPC} / \mathrm{CH} /$ complex at 5:3:1 molar ratio, SPC/CH/Complex/DSPE$\mathrm{PEG} 2000$ at 5:3:1:0.3 molar ratio, DSPC/CH/complex at 
5:3:1 molar ratio and DSPC/CH/Complex/DSPE-PEG2000 at 5:3:1:0.3 molar ratio.

The chloroform was removed under vacuum for $12 \mathrm{~h}$ leading to a thin lipid film. The MLV were formed by hydrating the lipid film with $0.15 \mathrm{~mol} \mathrm{~L}^{-1} \mathrm{NaCl}$ aqueous solution at $55{ }^{\circ} \mathrm{C}$ (final lipid concentration of $60 \mathrm{mmol} \mathrm{L}^{-1}$ ) and then shaking vigorously and vortexing the suspension for few minutes. The resulting liposome suspension was then submitted to repeated extrusions (five cycles) through two stacked polycarbonate membranes with pore diameter of $200 \mathrm{~nm}$ at $60^{\circ} \mathrm{C}$ and under high pressure of argon (500 psi).

\section{Characterization of liposomal platinum complex and stability}

In order to evaluate the stability of the drug encapsulation in liposomes, $1 \mathrm{~mL}$ of liposome suspension was submitted to dialysis across regenerated cellulose membrane (Spectra/ Por $^{\circledR}$ Biotech, MWCO:15000 Da) and against $1 \mathrm{~L}$ of $0.15 \mathrm{~mol} \mathrm{~L}^{-1} \mathrm{NaCl}$ under stirring at $25^{\circ} \mathrm{C}$ for $48 \mathrm{~h}$, changing the external solution each $12 \mathrm{~h}$.

The liposome samples obtained either before or after dialysis, were freeze-dried overnight.

The freeze-dried process was performed overnight using a Freeze dryer equipment (Labconco, Freezone 4.5) with frozen samples in liquid nitrogen. The dried samples were digested at $400{ }^{\circ} \mathrm{C}$ for $2 \mathrm{~h}$ and then solubilized in $\mathrm{HCl} /$ $\mathrm{HNO}_{3}(3: 1, \mathrm{v} / \mathrm{v})$ acid solution at $60{ }^{\circ} \mathrm{C}$.

The drug quantification was based on the platinum determination by flame atomic absorption (AA) using nitrous oxide-acetylene flame at $3000{ }^{\circ} \mathrm{C}$ (Hitachi $8200 \mathrm{AA}$ spectrometer). The method used was selective with optimal linear range up to $80 \mu \mathrm{g} \mathrm{mL}^{-1}$. Under the optimum condition the detection limit was found as $0.8 \mu \mathrm{g} \mathrm{mL}^{-1}$ for platinum in $\mathrm{HCl} / \mathrm{HNO}_{3}(3: 1, \mathrm{v} / \mathrm{v})$.

The encapsulation efficiency (EE\%) was calculated as: $\mathrm{EE} \%=100 \times($ amount of $\mathrm{Pt}$ in the sample by AA)/(initial amount of added Pt).

Particle size distribution was analyzed by photon correlation spectroscopy at $25^{\circ}$ and $90^{\circ} \mathrm{C}$ scattering angle using a channel correlation (Malvern Instruments, type $3000 \mathrm{HS}$ ) in conjunction with a He/Ne laser (wavelength $633 \mathrm{~nm}$ ). The samples were prepared by dilution of the liposome suspension in $0.15 \mathrm{~mol} \mathrm{~L}^{-1} \mathrm{NaCl}$ aqueous solution. The mean hydrodynamic diameter and polydispersity index were determined.

\section{Cytotoxicity assays}

The cytotoxic activity was investigated against tumor cell lines such as $\mathrm{A}_{549}$ - human non-small cell lung carcinoma (Cell Bank of the Federal University of Rio de Janeiro - Brazil), B16-F1 - mouse non-metastatic skin melanoma, B16-F10 - mouse metastatic skin melanoma, MDA-MB-231 - human breast adenocarcinoma (Ludwig Institute of Cancer Research - São Paulo - Brazil) and normal cell lines such as BHK-21 - Baby Hamster Kidney and $\mathrm{CHO}$ - Chinese Hamster Ovary (Centro Panamericano de Febre Aftosa - Rio de Janeiro - Brazil). All the cell lines were propagated in culture medium RPMI 1640 (Roswell Park Memorial Institute) pH 7.4, supplemented with $10 \%$ heat-inactivated fetal bovine serum (FBS), hepes $(4.0 \mathrm{mmol}$ $\left.\mathrm{L}^{-1}\right), \mathrm{NaHCO}_{3}\left(14.0 \mathrm{mmol} \mathrm{L}^{-1}\right)$, ampicillin $\left(0.27 \mathrm{mmol} \mathrm{L}^{-1}\right)$, and streptomycin $\left(0.06 \mathrm{mmol} \mathrm{L}^{-1}\right)$.

Cells were harvested by trypsinization and seeded in 96-well tissue culture plates $(100 \mu \mathrm{L} /$ well $)$ at different densities according to the cell line $\left(0.5 \times 10^{3}\right.$ to $2 \times 10^{3}$ viable cells/well) and incubated at $37{ }^{\circ} \mathrm{C}$ in a humidified atmosphere containing $5 \% \mathrm{CO}_{2}$ for $24 \mathrm{~h}$. Stock solutions of the test substances in DMSO were serially diluted in cell culture medium ( $<1 \%$ DMSO). After drug exposure for $120 \mathrm{~h}$ at $37^{\circ} \mathrm{C}$ and $5 \% \mathrm{CO}_{2}$, cells were incubated with MTT $\left(0.01 \mathrm{~mol} \mathrm{~L}^{-1}\right.$ in water solution - $10 \mu \mathrm{L} /$ well $)$ for $4 \mathrm{~h}$ at $37^{\circ} \mathrm{C}$ and $5 \% \mathrm{CO}_{2}{ }^{22}$ MTT is metabolized by viable cells resulting in a violet complex product that, after solubilization in $100 \mu \mathrm{L}$ of DMSO, can be quantified through colorimetric assay using ELISA reader (absorbance at $570 \mathrm{~nm}$ ).

The negative control (100\% value of viability) was obtained with cells exposure by RPMI 1640 medium supplemented with $10 \%$ FBS. Positive controls were also used against the cell lines, such as cisplatin and carboplatin.

The raw data were normalized to the untreated control cells and set into relation to the metabolic activity of the viable treated cells. $\mathrm{IC}_{50}$ values were calculated by four parametric nonlinear regression using GraphPad Prism 5.0 software (San Diego, USA). ${ }^{23}$

\section{Results and Discussion}

\section{Preparation and characterization of the liposome formulations}

In a first set of experiments, liposome formulations of complex 3 were prepared using different lipid compositions, in order to select the most appropriate composition with respect to the viability of the preparation process and the colloidal stability of the suspension. The formulations made from $\mathrm{CH} /$ complex (3:7 molar ratio), DCP/CH/complex (2:3:5 molar ratio), SPC/CH/complex (5:3:1 molar ratio) and SPC/CH/complex/DSPE-PEG2000 (5:3:1:0.3 molar ratio) could not be obtained because of either incomplete lipid film hydration (hydrated lipid sheets detached only partially from 
the sides of the round bottom flask following mechanical agitation) or non-effective filtration across polycarbonate membrane (the membrane has a tendency to foul with the liposomes suspension). On the other hand, the formulation made from DSPC/CH/complex (5:3:1 molar ratio) showed both effective hydration and extrusion steps, however it formed precipitates and, therefore, did not show adequate colloidal stability. When PEG-lipid was incorporated in the latter formulation (DSPC/CH/complex/DSPE-PEG2000 at 5:3:1:0.3 molar ratio), a stable colloidal suspension was achieved. Such improvement of the colloidal stability of the liposome suspension was indeed expected from the previous works performed with PEGylated liposomes. ${ }^{24}$

In a second set of experiments, the four different platinum complexes were incorporated in liposomes made from the selected lipid composition. Table 1 shows the characteristics of the resulting liposome preparations with respect to platinum encapsulation efficiency (EE\%) and particle size distribution (mean hydrodynamic diameter and polydispersity index).

$\mathrm{EE} \%$ was found to depend on the carbon chain length. complex 1 with the shortest alkyl chain (C8) showed the lowest value of $\mathrm{EE} \%$, whereas the other complex with a longer chain exhibited higher values. Such an increase in $\mathrm{EE} \%$ as a function of the chain length of the complex most probably arises from the enhanced binding of the complex to the liposome membrane as a result of its higher lipophilicity. Indeed, as shown in Table 1, determination of the lipophilicity of the different complexes through measurement of the octanol/water partition coefficient $(P)^{25}$ established a clear correlation between the lipophilicity of the complex and its alkyl chain length.

$P$ appears as a crucial parameter for the design of new platinum-based anticancer drugs, as it markedly influences important biological processes such as absorption, transmembrane transport, drug-receptor interactions and toxicity of molecules. ${ }^{26}$ In the present work, $P$ is shown to influence directly the $\mathrm{EE} \%$ in multilamellar vesicles.

The correlation between the EE\% and the lipophilicity of the complex also supports the model that the most lipophilic complexes are predominantly located at the water/lipid interface of the lipid vesicles. Nevertheless, more specific studied are still needed to confirm this localization.

According to the polydispersity index $(P I)$ of the liposome suspensions, MLV-1, MLV-3 and MLV-4, with $P I<0.2$, could be considered as monodisperse. The mean hydrodynamic diameter of the liposome suspensions was in the range of $150-160 \mathrm{~nm}$. Following storage of the formulations at $4{ }^{\circ} \mathrm{C}$ for 30 days, no change in the particle size distribution was observed. This is a strong indication of colloidal stability, even though the period of time is short when compared to the 6 months period of evaluation required by ANVISA, Agência Nacional de Vigilância Sanitária (http://www.anvisa.gov.br), for pharmaceutical formulations.

The ability of the formulation to retain the encapsulated platinum complex was assessed by submitting the liposome suspension to dialysis for $48 \mathrm{~h}$ at $25^{\circ} \mathrm{C}$ against saline at physiological concentration $\left(0.15 \mathrm{~mol} \mathrm{~L}^{-1} \mathrm{NaCl}\right)$. As shown in Table 1, only limited release of platinum was observed, indicating high retention of the drug from these formulations.

\section{Cytotoxic activity}

The cytotoxic activities of the complexes 1, 2, 3 and 4 and MLV-2, MLV-3 and MLV4 were assessed against different tumor and normal cell lines. Table 2 displays the results of the $\mathrm{IC}_{50}$ for these different drugs. The liposomal formulation containing complex 1 (MLV-1) was not evaluated because of very low EE\%. Liposomes prepared without the platinum complex (empty liposomes) did not show significant cytotoxicity (data not shown) confirming that the cytoxicicity is only caused by the complex.

Interestingly, the impact of liposome encapsulation on the cytotoxic activity of the complex was found to depend on the carbon chain length.

As illustrated in Figure 2, encapsulation of the C12derivative (complex 3) in liposomes (MLV-3) tended to increase its cytotoxicity in all cell lines. The most

Table 1. Characteristics of the liposome formulation ${ }^{\mathrm{a}}$ of the different $\mathrm{N}$-alkyl-propanediamine platinum complexes. Encapsulation efficiency (EE\%) before and after dialysis, mean hydrodynamic diameter, polydispersity index (polyindex)

\begin{tabular}{lcccccc}
\hline $\begin{array}{l}\text { Liposomal platinum } \\
\text { complexes }\end{array}$ & $\begin{array}{c}\text { Carbon chain } \\
\text { (number of C) }\end{array}$ & $\mathrm{P}^{\mathrm{b}}$ & $\begin{array}{c}\mathrm{EE} \\
\%\end{array}$ & $\begin{array}{c}\text { EE (after dialysis) } \\
\%\end{array}$ & Polyindex & Diameter (nm) \\
\hline MLV-1 & 8 & 2.21 & 18.5 & 7.1 & 0.084 & 157 \\
MLV-2 & 10 & 20.05 & 46.0 & 39.5 & 0.260 & 158 \\
MLV-3 & 12 & 33.70 & 82.4 & 71.0 & 0.045 & 159 \\
MLV-4 & 14 & 46.42 & 86.3 & 72.0 & 0.047 & 157 \\
\hline
\end{tabular}

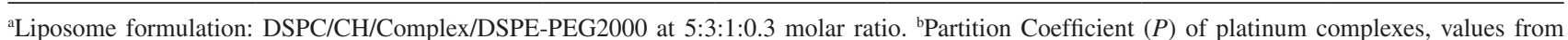
previous work. ${ }^{19}$ 
Table 2. Cytotoxicity of lipophilic platinum complexes and their respective liposomes formulations ${ }^{\mathrm{a}}$

\begin{tabular}{|c|c|c|c|c|c|c|}
\hline \multirow[t]{3}{*}{ Complexes } & \multicolumn{6}{|c|}{$\mathrm{IC}_{50}\left(\mu \mathrm{mol} \mathrm{L^{-1 }}\right)^{\mathrm{b}}$} \\
\hline & \multicolumn{4}{|c|}{ Tumor cell lines } & \multicolumn{2}{|c|}{ Non-tumor cell lines } \\
\hline & B16-F1 & B16-F10 & MDA-MB-231 & $\mathrm{A}_{549}$ & BHK-21 & $\mathrm{CHO}$ \\
\hline 1 & 20.8 & 10.9 & 7.2 & 19.1 & 4.2 & 1.8 \\
\hline 2 & 16.5 & 15.8 & 16.5 & 16.5 & 12.5 & 9.5 \\
\hline MLV-2 & 14.4 & 6.3 & 25.1 & 14.4 & 22.9 & 3.6 \\
\hline 3 & 4.1 & 6.3 & 4.2 & 15.8 & 7.6 & 6.3 \\
\hline MLV-3 & 2.7 & 4.2 & 3.9 & 4.2 & 7.2 & 3.9 \\
\hline 4 & 5.1 & 8.3 & 8.5 & 4.6 & 5.5 & 5.2 \\
\hline MLV-4 & 14.5 & 9.8 & 15.9 & 19.1 & 19.0 & 6.2 \\
\hline Cisplatin & 3.5 & 4.2 & 1.4 & 2.7 & 3.6 & 5.5 \\
\hline Carboplatin & 6.3 & 6.3 & 8.3 & 20.1 & 50.6 & 9.8 \\
\hline
\end{tabular}

aLiposome formulation: DSPC/CH/Complex/DSPE-PEG2000 at 5:3:1:0.3 molar ratio. 'inhibitory concentration of 50\% of cell growth are presented as mean values of a triplicate determination (standard deviation < 10\%). Tumor Cell lines B16-F1 (mouse non-metastatic skin melanoma), B16-F10 (mouse metastatic skin melanoma), MDA-MB-231 (human breast adenocarcinoma), $\mathrm{A}_{549}$ (human non-small cell lung carcinoma) and Normal Cell lines BHK-21 (baby hamster kidney) and $\mathrm{CHO}$ (Chinese hamster ovary).

pronounced effect was observed in the $\mathrm{A}_{549}$ cell line, with a 3- to 4-fold increase. The MLV-3 liposome formulation was more effective than carboplatin in all cell lines and showed results as good as those of cisplatin in melanoma cell lines (B16-F1 and B16-F10). MLV-3 appeared to be less toxic than cisplatin in normal kidney cells ( $\mathrm{p}<0.001$, $t$-student test). This suggests a lower nephrotoxicity during the therapy, one of the most severe side effects caused by cisplatin.

On the other hand, the encapsulation of the C14derivative (complex 4) in liposomes (MLV-4) showed an opposite tendency. The complex showed a higher cytotoxicity in the free form, presumably because of lower bioavailability and tendency to transfer from the liposome to the cell membrane.

Finally, no general tendency was observed in the case of the C10-derivative (complex 2) in liposomes (MLV-2).

These data suggest that the highest drug bioavailability from liposome formulations is achieved with the complex showing an intermediate carbon chain length and partition between the liposome membrane and aqueous phase.

In previous work, these complexes were investigated, in the non-encapsulated form, to evaluate the influence of the carbon chain length on their cellular uptake. It was reported that the increase of the carbon chain of the complex facilitated its uptake by cells and enhanced its cytotoxicity against GLC4 (lung cancer cell line) and K562 (leukemia myelogenic cell line). ${ }^{19}$ The same trend of cytotoxicity was observed in the case of non-encapsulated complexes: complex $\mathbf{2}<$ complex $\mathbf{3} \approx$ complex 4 . However, a different cytotoxicity profile is now reported in the case of liposome-encapsulated complexes: complex $\mathbf{2}<$ complex $\mathbf{3}>$ complex $\mathbf{4}$, supporting the idea that liposome encapsulation modulates the drug activity.

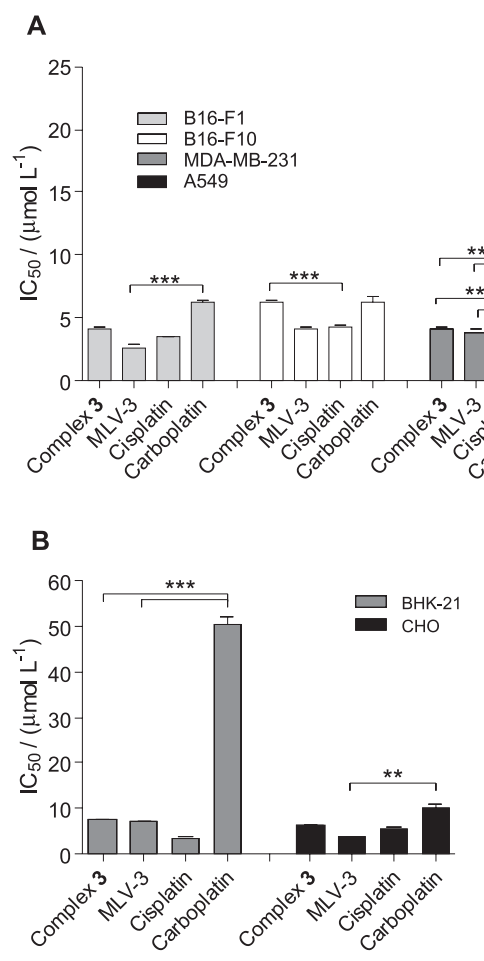

Figure 2. Effect of several $N$-alkyl-propanediamine platinum complexes on the viability of (A) tumor cells (B16-F1, B16-F10, MDA-MB-231 and $\mathrm{A}_{549}$ ) and (B) normal cells (BHK-21 and $\mathrm{CHO}$ ); incubated for $120 \mathrm{~h}$ in complete RPMI- 1640 medium at $37{ }^{\circ} \mathrm{C}$ in a $5 \% \mathrm{CO}_{2}$. The cytotoxicity was assessed employing tetrazolium bromide reduction method (MTT). Values represent the average of two independent experiments performed in triplicate. The differences among the experimental groups were compared using the variance analysis (ANOVA) followed by Bonferroni, $*(\mathrm{p}<0.05), * *(\mathrm{p}<0.01)$ and $* * *(\mathrm{p}<0.001)$. 


\section{Conclusions}

The present work brings new insights into the influence of the carbon chain length/partition coefficient of lipophilic platinum drugs on their bioavailability from a liposome carrier. Importantly, our data indicates that the highest drug bioavailability from the liposome formulation was achieved with the complex having intermediate carbon chain length and partition between the liposome membrane and aqueous phase. Thus, it is suggested that lipophilic drugs with high partition into the liposome membrane may not be advantageous for liposome-mediated delivery to tumor cells. The liposome formulation containing the C12-derivative platinum complex was more effective against tumor cell lines than the free drug and appears as the most promising formulation for future in vivo antitumor activity evaluations.

\section{Acknowledgments}

To CNPq and FAPEMIG for financial support and fellowship.

\section{References}

1. Pratt, W. B.; Ruddon, R. W.; Ensminger, W. D.; Maybaum, J.; The Anticancer Drugs, Oxford University Press: New York; 1994, pp. 133-139.

2. Hambley, T. W.; Coord. Chem. Rev. 1997, 166, 181.

3. Natile, G.; Coluccia, M.; Coord. Chem. Rev. 2001, 216-217, 383.

4. Sykes, A. G.; Platinum Metals Rev. 1988, 32, 170.

5. Pasini, A.; Zunino, F.; Angew Chem., Int. Ed. Engl. 1987, 26, 615.

6. Farrell, N.; Qu, Y.; Hacker, M. P.; J. Med. Chem. 1990, 33, 2179.

7. Siddik, Z. H.; Oncogene 2003, 22, 7265.

8. Johnson, S. W.; Ferry, K. V.; Hamilton, T. C.; Drug Res. Updates 1998, 1, 243.

9. Ye, Q. S.; Lou, L. G.; Liu, W. P.; Yu, Y.; Chen, X. Z.; Hou, S. Q.; Gao, W. Q.; Liu, Y.; Bioorg. Med. Chem. Lett. 2007, 17, 2144.

10. Halámidová, A.; Heringová, P.; Kaspárková, J.; Intini, F. P.; Natile, G.; Nemirovski, A.; Gibson, D.; Brabec, V.; J. Inorg. Biochem. 2008, 102, 1077.
11. Peer, D.; Karp, J. M.; Hong, S.; Farokhzad, O. C.; Margalit, R.; Langer, R.; Nature Nanotech. 2007, 2, 751.

12. Perez-Soler, R.; Khokhar, A. R.; Cancer Res. 1992, 52, 6341.

13. Han, I.; Jun, M. S.; Kim, M. K.; Kim, J. C.; Sohn, Jpn., Y. S.; J. Cancer Res. 2002, 93, 1244.

14. Fahr, A.; Hoogevest, P.; May, S.; Bergstrand, N.; Leigh, M. L. S.; Eur. J. Pharmacol. Sci. 2005 26, 251.

15. Harrington, K. J.; Rowlinson-Busza, G.; Syrigos, K. N.; Uster, P. S.; Vile, R. G.; Stewart, J. S. W.; Clin. Cancer Res. 2000, 6, 2528.

16. Verrecchia, T.; Spenlehauer, G.; Bazile, D. V.; Murry-Brelier, A.; Archimbau, Y.; Veillard M.; J. Control. Releas. 1995, 36, 49.

17. Carvalho Júnior, A. D.; Vieira, F. P.; De Melo, V. J.; Lopes, M. T. P.; Silveira, J. N.; Ramaldes, G. A.; Garnier-Suillerot, A.; Pereira-Maia, E. C.; De Oliveira, M. C.; Braz. J. Med. Biol. Res. 2007, 40, 1149.

18. Mayer, L. D.; Shabbits, J. A.; Cancer Metastasis Rev. 2001, 20 , 87.

19. Silva, H.; Barra, C. V.; da Costa, C. F.; de Almeida, M. V.; César, E. T.; Silveira, J. N.; Garnier-Suillerot, A.; de Paula, F. C. S.; Pereira-Maia, E. C.; Fontes. A. P. S.; J. Inorg. Biochem. 2008, 102,767

20. Frezard, F.; Schettini, D. A.; Rocha, O. G. F.; Demicheli, C.; Quim. Nova 2005, 28, 511.

21. Nayar, R.; Hope, M. J.; Cullis, P. R.; Biochim. Biophys. Acta 1989, 986, 200.

22. Silva, H.; Barra, C.; Rocha, F.; de Almeida, M. V.; Cesar, E. T.; Siqueira, L. M. S.; Lopes, M. T. P.; Fontes, A. P. S.; Chem. Biol. Drug Des. 2010, 75, 407.

23. Garmann, D.; Warnecke, A.; Kalayda, G. V.; Kratz, F.; Jaehde, U.; J. Control. Release 2008, 131, 100.

24. Woodle, M. C.; Lasic, D. D.; Biochim. Biophys. Acta 1992, 1113,171

25. Guerra, W.; Silva, I. R.; Azevedo, E. A.; Monteiro, A. R. S.; Bucciar- elli-Rodriguez, M.; Chartone-Souza, E.; Silveira, J. N.; Fontes, A. P .S.; Pereira-Maia, E. C.; J. Braz. Chem. Soc. 2006, 17, 1627.

26. Tetko, I. V.; Jaroszewicz, I.; Platts, J. A.; Kuduk-Jaworska, J.; J. Inorg. Biochem. 2008, 102, 1424.

Submitted: January 30, 2010 Published online: June 23, 2010 